\title{
EDAG regulates the proliferation and differentiation of hematopoietic cells and resists cell apoptosis through the activation of nuclear factor- $\kappa B$
}

\author{
CY Li ${ }^{1}$, YQ Zhan ${ }^{1}$, CW Xu' ${ }^{1}$, WX Xu ${ }^{1}$, SY Wang ${ }^{1,2}$, J Lv $^{1}$, Y Zhou ${ }^{1,2}$, \\ PB Yue ${ }^{1}$, B Chen $^{1,2}$ and XM Yang ${ }^{*, 1}$ \\ 1 Beijing Institute of Radiation Medicine, Beijing 100850, PR China \\ 2 Department of Pathology of Anhui Medical University, Hefei 230000, PR China \\ * Corresponding author: XM Yang, Beijing Institute of Radiation Medicine, 27 \\ Taiping Road, Beijing 100850, PR China. Tel: + 8610 66931424; \\ Fax: + 8610 68212874; E-mail: xmyang2@ nic.bmi.ac.cn or \\ xiaomingyang@sina.com
}

Received 25.3.04; revised 18.5.04; accepted 16.6.04; published online 27.8.04 Edited by J Cidlowski

\begin{abstract}
Erythroid differentiation-associated gene (EDAG) is considered to be a human hematopoiesis-specific gene. Here, we reported that downregulation of EDAG protein in K562 cells resulted in inhibition of growth and colony formation, and enhancement of sensitivity to erythroid differentiation induced by hemin. Overexpression of EDAG in HL-60 cells significantly blocked the expression of the monocyte/ macrophage differentiation marker CD11b after pentahydroxytiglia myristate acetate induction. Moreover, overexpression of EDAG in pro- $B \mathrm{Ba} / \mathrm{F} 3$ cells prolonged survival and increased the expression of $\mathrm{C}-\mathrm{Myc}, \mathrm{Bcl}-2$ and $\mathrm{Bcl}-\mathrm{xL}$ in the absence of interleukin-3 (IL-3). Furthermore, we showed that EDAG enhanced the transcriptional activity of nuclear factorkappa B (NF- $\kappa$ B), and high DNA-binding activity of NF- $\kappa$ B was sustained in $\mathrm{Ba} / \mathrm{F} 3$ EDAG cells after IL-3 was withdrawn. Inhibition of NF- $\kappa$ B activity resulted in promoting Ba/F3 EDAG cells death. These results suggest that EDAG regulates the proliferation and differentiation of hematopoietic cells and resists cell apoptosis through the activation of NF- $\kappa$ B.

Cell Death and Differentiation (2004) 11, 1299-1308.

doi:10.1038/s..cdd. 4401490

Published online 27 August 2004
\end{abstract}

Keywords: EDAG; NF- $\kappa \mathrm{B}$; proliferation; differentiation; apoptosis

Abbreviations: $A L L$, acute lymphoblastic leukemia; $A M L$, acute myeloid leukemia; ANLL, acute nonlymphoblastic leukemia; AS, antisense; ATRA, all trans retinoic acid; CML, chronic myeloid leukemia; EDAG, erythroid differentiation-associated gene; EMSA, electrophoretic mobility shift assay; EPO, erythropoietin; FCS, fetal calf serum; FITC, fluorescein isothiocyanate; IL-2, interleukin-2; IL-3, interleukin-3; MDS, myelodysplastic syndrome; NF- $\kappa$ B, nuclear factor-kappa B; PBMCs, peripheral blood mononuclear cells; PBS, phosphate-buffered saline; PHA, phytohemagglutinin; PMA, pentahydroxytiglia myristate acetate; RT-PCR, reverse transcription-polymerase chain reaction

\section{Introduction}

Erythroid differentiation-associated gene (EDAG), which is homologous to mouse hemogen ${ }^{1}$ and rat RP59, ${ }^{2}$ is identified by using the polymerase chain reaction (PCR)-based subtractive hybridization method. ${ }^{3}$ In a previous study, Yang et al. ${ }^{1}$ found that hemogen transcripts are specifically detected in blood islands, primitive blood cells and fetal liver and downregulated in the process of blood cell differentiation during mouse embryogenesis, then remain in the bone marrow and spleen in adult mice. ${ }^{1}$ Just like hemogen, EDAG exhibits specific expression in human hematopoietic tissues and cells, ${ }^{1}$ including the adult bone marrow and fetal liver, and no EDAG transcripts are detected in the adult liver, heart, brain, skeletal muscle, kidney, spleen, pancreas, tonsil, colon and peripheral blood mononuclear cells (PBMCs). ${ }^{4}$ Moreover, the expression of EDAG mRNA in leukemia cell lines K562 and MO7e is very high. ${ }^{4}$ When K562 cells are induced to differentiate toward erythroid or megakaryocytic phenotypes in response to hemin, erythropoietin (EPO) or pentahydroxytiglia myristate acetate (PMA), EDAG is quickly downregulated in a time-dependent manner. ${ }^{4}$ Functionally, our previous study also shows that the overexpression of EDAG in NIH3T3 cells results in malignant transformation of the cells characterized by cell morphology, anchorage-independent growth and tumorigenicity in nude mice. ${ }^{5}$ The EDAG gene is mapped to chromosome 9q22, ${ }^{1}$ a region that contains the break points of several hematopoietic neoplasms. ${ }^{6}$ Taken together, these data suggest that the EDAG gene might play an important role in hematopoietic development and neoplasms. Unlike hemogen and EDAG, the rat homolog RP59 is found in the cells of the primitive ectoderm and primitive streak as well as in blood islands and extraembryonal mesoderm. Later, RP59 occurred in fetal liver cells and in circulating blood. From the time around birth, it is found in the bone marrow and spleen cells. In addition, in vitro-formed blood vessels contain RP59-positive cells in the lumen, but endothelial cells and the vast majority of cells outside the blood vessels are not labeled. With regard to more mature hematopoietic cell types, RP59 is observed in megakaryocytes and nucleated erythroblasts, but absent from lymphoid cells. $^{7}$

Sequence analysis has suggested that the $\mathrm{N}$-terminus of EDAG protein contains a weak nuclear location signal (NLS), which is highly conserved in hemogen ${ }^{1}$ and RP59. ${ }^{2}$ Although immunohistochemical analysis has indicated a strong presence of RP59 in the cytoplasm of bone marrow cells and a weaker presence in the nuclei of osteoblasts, hemogen is located in the nucleus by the immunostaining method. Using the liver color-fluorescent protein method, we also identify the presence of EDAG-GFP protein in the nucleus. ${ }^{5}$ The different location of these homologous genes may be due to the differences in species and cell types. Also, the same location 
of EDAG and hemogen may suggest a similar biological function in humans and mice.

Here, we show that human EDAG mRNA is highly expressed in human leukemia cells and mitogen-stimulated primary PBMCs. Using K562, HL-60 and Ba/F3 cells as models, EDAG is characterized as a molecular regulator of proliferation and differentiation in hematopoietic cells, and resists cell apoptosis through the activation of nuclear factorkappa B (NF- $\kappa \mathrm{B})$.

\section{Results}

\section{EDAG is specifically expressed in lymphoma and PBMCs of patients with leukemia}

As shown in Figure 1a, the level of EDAG expression was very low in different human adult normal tissues; however, the expression of EDAG mRNA was significantly upregulated about 20-, 30- and 35-fold in thymus tumor, thyroid tumor, and non-Hodgkin's lymphoma, respectively, as compared to that in the corresponding normal tissues. Moreover, high levels of EDAG mRNA were detected in PBMCs of patients with acute myeloid leukemia (AML), acute nonlymphoblastic leukemia (ANLL), acute lymphoplastic leukemia (ALL) and chronic myeloid leukemia $(\mathrm{CML})$, but not in solid tumors originating from the colon, rectum, lung, liver, and gastric tissue or in the PBMCs of normal donors (Figure 1a, Table 1).

\section{Mitogen-induced expression of EDAG mRNA in primary human PBMCs}

To detect whether mitogen could induce the expression of EDAG mRNA in PBMCs, the level of EDAG transcripts was determined by semiquantitative reverse transcription-polymerase chain reaction (RT-PCR) analysis. The PCR

Table 1 EDAG expression in human cancer

\begin{tabular}{lc}
\hline Diagnosis & Patients expressing EDAG RNA ${ }^{\mathrm{a}}$ /total analyzed \\
\hline ALL & $6 / 10$ \\
ANLL & $2 / 6$ \\
CML & $4 / 7$ \\
AML & $4 / 6$ \\
Lymphocytoma & $2 / 4$ \\
MDS & $0 / 4$ \\
Other & $0 / 24$ \\
Healthy donors & $0 / 10$ \\
\hline
\end{tabular}

aEDAG mRNA was detected by the Northern blotting method. The expression of G3PDH mRNA was used as an internal control. ${ }^{b}$ Includes solid tissue from four colon tumors, six rectum tumors, seven lung cancers, four gastric tumors and three hepatoma cancers.

a

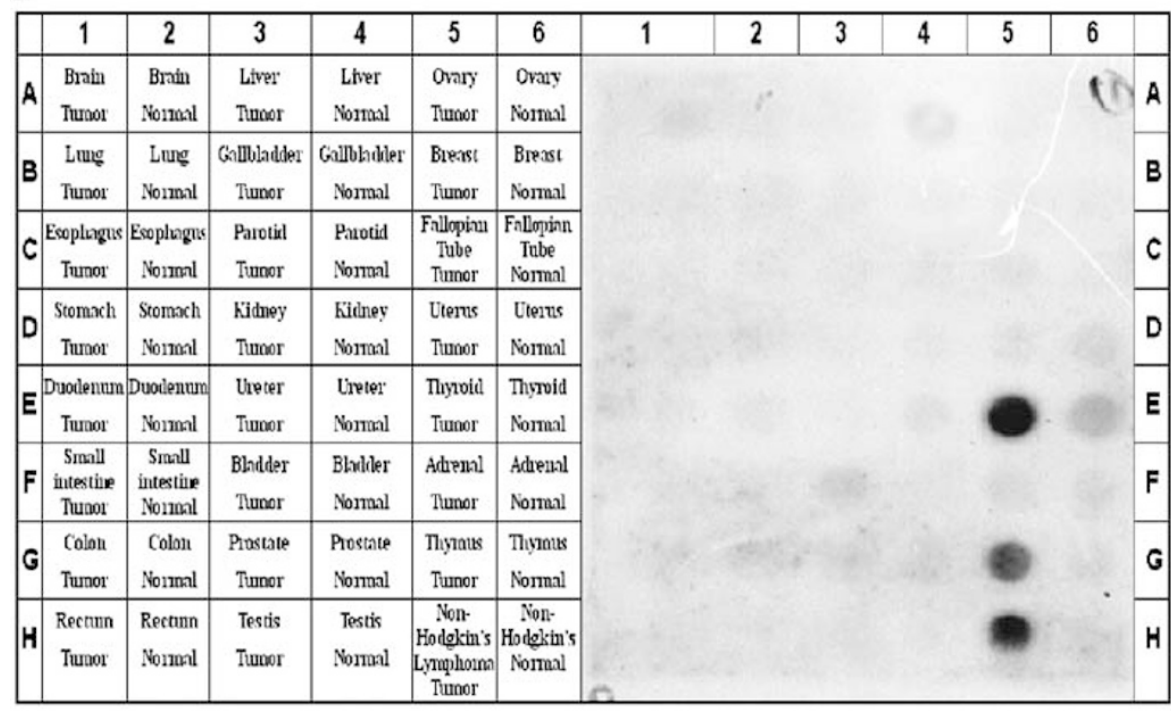

b

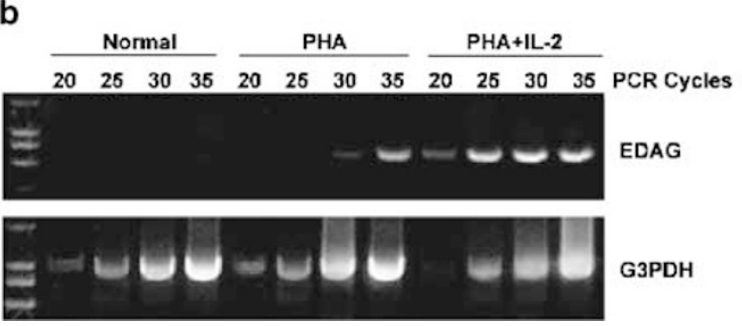

Figure 1 (a) Expression of EDAG transcript in 24 different human tumors and normal controls. Slot blots containing 24 different human tumors and normal controls (BioChain Institute Inc., Cat\# H1235706) were hybridized with EDAG probe. (b) Mitogen-induced expression of EDAG mRNA. Total RNA was prepared from pooled human PBMCs from four healthy donors after stimulation with $5 \mu \mathrm{g} / \mathrm{ml} \mathrm{PHA}$ with or without $6000 \mathrm{IU} / \mathrm{ml} \mathrm{IL-2}$ for $48 \mathrm{~h}$. The level of EDAG mRNA was determined by semiquantitative RT-PCR. The PCR amplification was carried out at a varying number of cycles as indicated. G3PDH was used as an internal control 
amplification was performed at a various number of cycles. As shown in Figure 1b, EDAG mRNA was detectable at cycle 30 in the phytohemagglutinin (PHA)-treated cells and at cycle 20 in cells treated with both PHA and interleukin-2 (IL-2). However, there was no detectable EDAG mRNA in the resting normal PBMCs, even when the number of PCR cycles was increased to 35 .

\section{Expression of EDAG promotes the growth and inhibits the differentiation sensitivity of K562 cells}

To investigate the correlation between EDAG expression and cell proliferation and differentiation, two K562/EDAG monoclonal cell lines stably expressing zinc-inducible EDAG antisense (AS) were established by transfecting with a linearized $\mathrm{pHSC}$-EDAG-R vector, in which a high level of EDAG AS RNA was induced (data not shown) and the level of EDAG protein was reduced after treatment with $80 \mu \mathrm{M} \mathrm{ZnSO}_{4}$ for $24 \mathrm{~h}$ (Figure $2 \mathrm{a}$, left). As Figure $2 \mathrm{a}$ (right) shows, the reduction of EDAG protein in K562/EDAG AS-1 cells was time-dependent, and there was a $60 \%$ decrease in EDAG expression $48 \mathrm{~h}$ after $80 \mu \mathrm{M} \mathrm{ZnSO}{ }_{4}$ treatment. To analyze whether the inhibition of EDAG affects the proliferation of K562 cells, K562/EDAG AS-1, K562/EDAG AS-2, Wt K562 (wild-type K562) and parental K562 (mock transfectants) cells were cultured in the presence or absence of $\mathrm{ZnSO}_{4}$. No significant difference was observed in the growth kinetics of all these cells in the absence of $\mathrm{ZnSO}_{4}$. However, the growth of $\mathrm{K} 562 / E D A G$ AS cells was markedly reduced in a $\mathrm{ZnSO}_{4}$ dosedependent manner (Figure 2b). Colony formation assay also confirmed that the number of colonies formed by K562/EDAG AS cells was decreased remarkably when treated with $\mathrm{ZnSO}_{4}$, but no significant reduction in the number of colonies was observed in Wt K562 and parental K562 cells (Figure 2c).

To assess the role of EDAG in erythroid differentiation, a benzidine oxidation test was performed to determine the peroxidase activity of K562 cells, which reflects the content of hemoglobin and the degree of differentiation. As in shown Figure 2d, the differentiation response of K562/EDAG AS cells was weak when cultured with hemin in the absence of $\mathrm{ZnSO}_{4}$. However, in the presence of $\mathrm{ZnSO}_{4}$, the K562/EDAG AS cells strongly responded to hemin - that is, K562/EDAG AS cells increased the differentiation sensitivity about twofold. By contrast, only very weak differentiation was observed in parental $\mathrm{K} 562$ and Wt K562 cells with or without $\mathrm{ZnSO}_{4}$.

\section{Downregulation of c-Myc during expression of EDAG AS}

As shown in Figure 2e, the level of c-Myc protein decreased significantly after treatment with $80 \mu \mathrm{M} \mathrm{ZnSO}_{4}$ in K562/EDAG AS cells, which agrees with the expression pattern of EDAG protein. However, we did not detect such an expression pattern of c-Myc in the parental K562 cells.

\section{Overexpression of EDAG inhibits the differentiation of HL-60 cells}

To further evaluate the role of EDAG in the differentiation of leukemia cells, two stable HL-60 monoclonal cell lines expressing different levels of EDAG protein, HL-60/EDAG-1 and HL-60/EDAG-2, were established (Figure 3a). Then the cells were treated with PMA to determine their sensitivity to undergo monocyte/macrophage differentiation. PMA treatment resulted in a pronounced alteration in the adhesive and spreading properties in parental HL-60 cells. However, the overexpression of EDAG in HL-60/EDAG-2 cells significantly inhibited cell adhesion and spreading activity when they were treated with PMA (Figure 3b). Flow cytometry analysis revealed that after 4 days of PMA induction, $95 \%$ of parental cells expressed CD11b, a specific monocyte/macrophage differentiation marker, ${ }^{8}$ whereas only $78 \%$ of HL-60/EDAG-1 cells and $21 \%$ of HL-60/EDAG-2 cells were positive for this marker, suggesting a positive correlation between the level of EDAG expression and the percent of CD11b-positive cells (Figure 3c).

\section{Overexpression of EDAG prolongs survival in IL-3-dependent $\mathrm{Ba} / \mathrm{F3}$ cells}

To examine whether overexpression of EDAG could abolish the interleukin-3 (IL-3) dependence of $\mathrm{Ba} / \mathrm{F3}$ cells, we established four $\mathrm{Ba} / \mathrm{F} 3$ cell lines: $\mathrm{Ba} / \mathrm{F} 3$ EDAG (Ba/F3 cells stably transfected with pcDNA-EDAG), Ba/F3 $\triangle E D A G$ (stably transfected with pcDNA- $\triangle E D A G$ ), parental $\mathrm{Ba} / \mathrm{F3}$ (transfected with pcDNA) and Wt Ba/F3 (wild-type $\mathrm{Ba} / \mathrm{F3}$ ) cells, and EDAG expression was detected (Figure 4a). These four cell lines were cultured in the absence of IL-3, and viable cells were counted by trypan blue staining. After IL-3 was withdrawn for $48 \mathrm{~h}, \mathrm{Ba} / \mathrm{F} 3 \mathrm{EDAG}$ cultures still contained many live cells, and the average viability was $75 \pm 2 \%$, whereas that of $\mathrm{Ba} / \mathrm{F} 3 \Delta \mathrm{EDAG}$, parental $\mathrm{Ba} / \mathrm{F} 3$ and $\mathrm{Wt} \mathrm{Ba} / \mathrm{F} 3$ cells was only $8 \pm 1,5 \pm 1$ and $3 \pm 1 \%$, respectively (Figure $4 b$ ); however, no long-term cytokine-independent growth was observed in any of the cell lines. Although Ba/F3 EDAG cells did not proliferate without IL-3, they grew normally after the readdition of IL-3, even 10 days after withdrawal.

To confirm that the improvement of the viability of the $\mathrm{Ba} / \mathrm{F3}$ EDAG cells was secondary to a decrease in the percentage of cells undergoing apoptosis, cells were cultured without IL-3 for $12 \mathrm{~h}$ and harvested for cell cycle analysis. When cultured in normal medium, the four cell lines all showed a typical cell cycle and no significant apoptosis was detected. However, under IL-3 starvation, Ba/F3 $\mathrm{EDAG}$, parental $\mathrm{Ba} / \mathrm{F} 3$ and $\mathrm{Wt}$ $\mathrm{Ba} / \mathrm{F} 3$ cells extensively underwent apoptosis $(65,68$ and $70 \%$, respectively), whereas $\mathrm{Ba} / \mathrm{F3}$ EDAG cells were arrested in the $\mathrm{G}_{0} / \mathrm{G}_{1}$ phase $(56.83 \%)$, and only $9 \%$ of cells underwent apoptosis (Figure 4c).

\section{EDAG enhances NF- $\kappa$ B DNA-binding and transcriptional activity}

$\mathrm{NF}-\kappa \mathrm{B}$ plays an essential role in the survival of $\mathrm{Ba} / \mathrm{F} 3$ cells. To determine whether the overexpression of EDAG can lead to the induction of $\mathrm{NF}-\kappa \mathrm{B}, \mathrm{Ba} / \mathrm{F} 3 \mathrm{EDAG}$ and parental $\mathrm{Ba} / \mathrm{F} 3$ cells were cultured in IL-3 starvation medium for the indicated time, and nuclear extracts were analyzed by electrophoretic mobility shift assay (EMSA). The DNA-binding activity of $\mathrm{NF}-\kappa \mathrm{B}$ in $\mathrm{Ba} / \mathrm{F} 3 \mathrm{EDAG}$ cells increased seven-fold relative to 
a
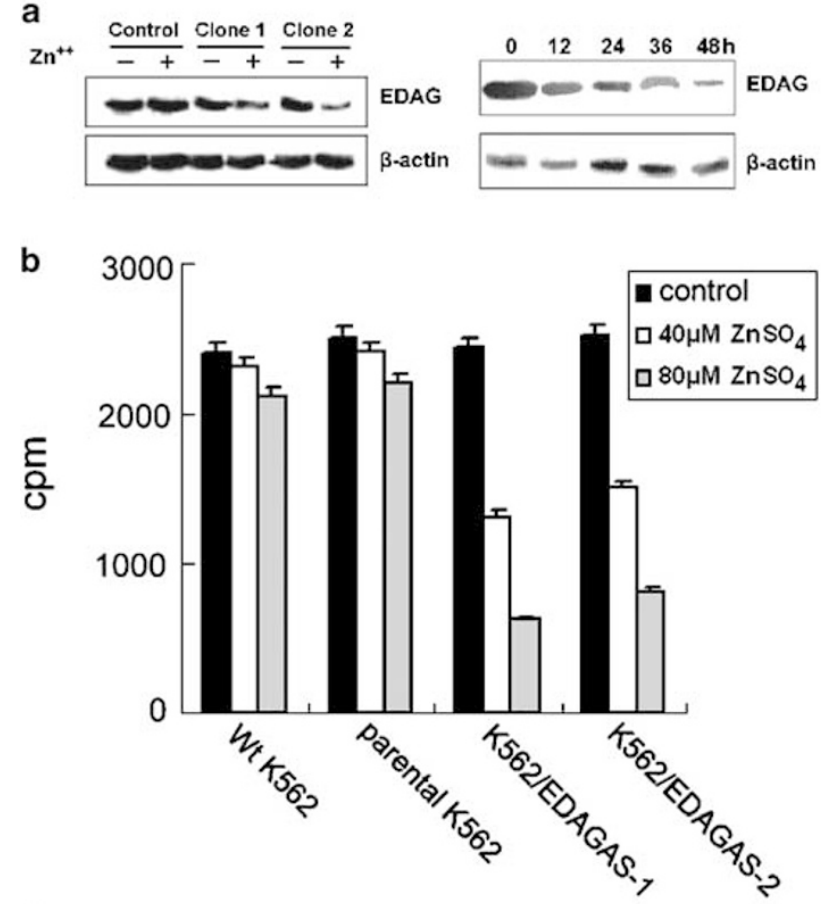

C

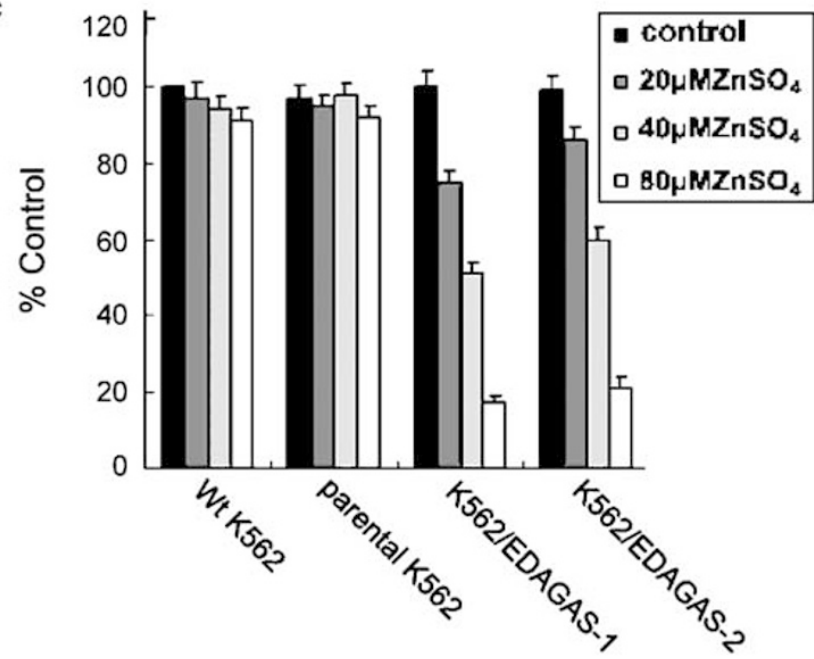

d

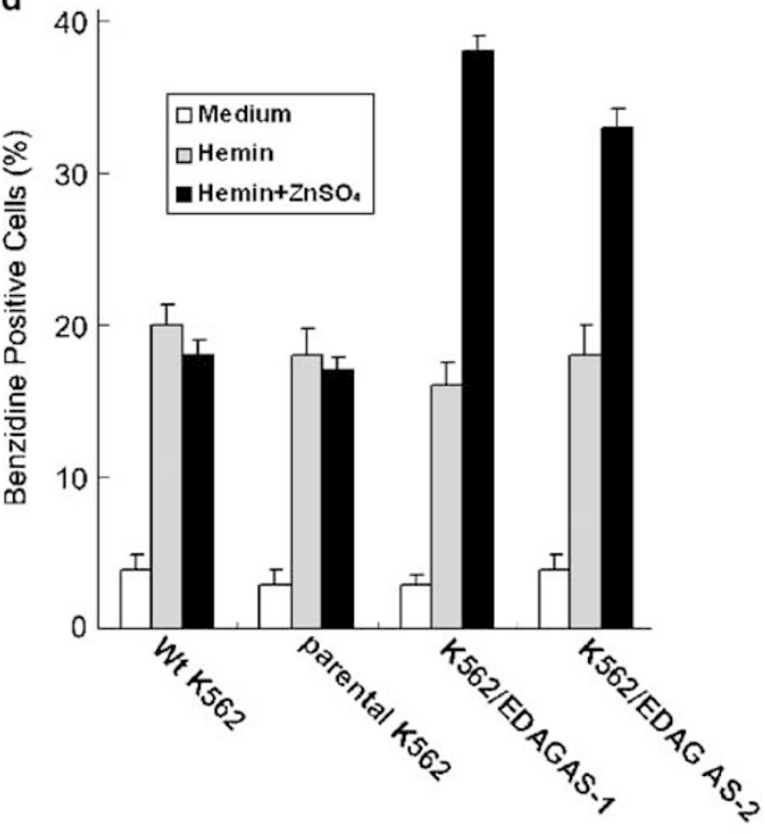

e

e EDAGIAS

$0 \quad 61224364872 \mathrm{~h}$

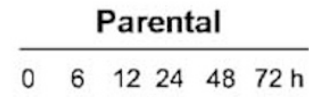

$\boldsymbol{\omega} \boldsymbol{0} \boldsymbol{0}-\cdots$

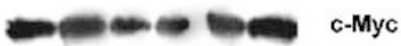

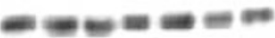

$\beta$-actin

Figure 2 The effect of EDAG on the proliferation and differentiation of K562 cells. A total of (a) $1 \times 10^{5}$ cells of K562 EDAG/AS clone 1 and clone 2 or parental K562 were exposed to $80 \mu \mathrm{M}$ of $\mathrm{ZnSO}_{4}$ for $24 \mathrm{~h}$, and the levels of EDAG protein were detected by Western blotting analysis (left). Clone1 cells were exposed to $80 \mu \mathrm{M} \mathrm{ZnSO}{ }_{4}$ for the indicated time, then EDAG protein was detected by Western blotting analysis (right). $\beta$-Actin was used as an internal control. (b) $\mathrm{A}$ total of $3 \times 10^{4}$ cells were seeded in 96-well plates and treated with different concentrations of $\mathrm{ZnSO}_{4}$ for $48 \mathrm{~h}$, and cell growth was determined by [ ${ }^{3} \mathrm{H}$ thymidine assay. Data shown are means \pm s.e. from three independent experiments. (c) Wt K562, parental K562 and K562/EDAG AS cells were plated in triplicate for colony formation assay in 35-mm well. After 2 weeks, colonies containing more than 50 cells were scored. (d) Expression of EDAG antisense enhances the erythroid differentiation of K562 cells. Parental K562 or K562/EDAG AS cells were treated with $40 \mu \mathrm{M}$ hemin with or without $30 \mu \mathrm{M} \mathrm{ZnSO}{ }_{4}$ for 3 days and then stained with benzidine. Benzidine-positive cells were counted. (e) Expression of c-Myc in K562 cells. K562 EDAG/AS and parental K562 cells were exposed to $80 \mu \mathrm{M} \mathrm{ZnSO}{ }_{4}$ for the indicated time, and the expression of $\mathrm{c}-$ Myc was analyzed by Western blotting

that in parental cells after IL-3 was withdrawn for 6-12 h (Figure 5a). Supershift assays revealed that the $\mathrm{NF}-\kappa \mathrm{B}$ complex is composed of p65/p50 and p50/p50.

To determine the transcriptional activity of the activated NF$\kappa \mathrm{B}$, we performed a luciferase reporter assay. A plasmid that contained a promoter composed of three NF- $\kappa$ B-binding sites linked to a luciferase reporter gene $(3 \times \kappa \mathrm{B}-\mathrm{Luc})$ was transfected into $\mathrm{Ba} / \mathrm{F} 3 \Delta \mathrm{EDAG}$, parental $\mathrm{Ba} / \mathrm{F} 3$ and $\mathrm{Ba} / \mathrm{F} 3$ EDAG cells. After transfection, cells were cultured for $36 \mathrm{~h}$ in the presence of $0.2 \mathrm{ng} / \mathrm{ml} \mathrm{IL-3}$, and the relative luciferase activities of cell lysates were measured. As shown in Figure $5 b$, the luciferase activity in $\mathrm{Ba} / \mathrm{F} 3$ EDAG cells was about five-fold higher than that in Wt Ba/F3, Ba/F3 $\triangle E D A G$ and parental $\mathrm{Ba} / \mathrm{F} 3$ cells. Furthermore, our observation that the activation of $\mathrm{NF}-\kappa \mathrm{B}$ by EDAG could be blocked by transfection of a $\mathrm{p}-\mathrm{CMV}-\mathrm{I}_{\kappa} \mathrm{B} \alpha \mathrm{M}(\mathrm{A} 32 / 36)$ plasmid coding for a mutant $I_{\kappa} \mathrm{B} \alpha$, which cannot be phosphorylated on stimulation, suggests that EDAG may regulate the nuclear accumulation 


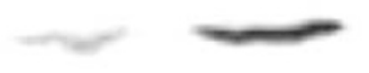

EDAG
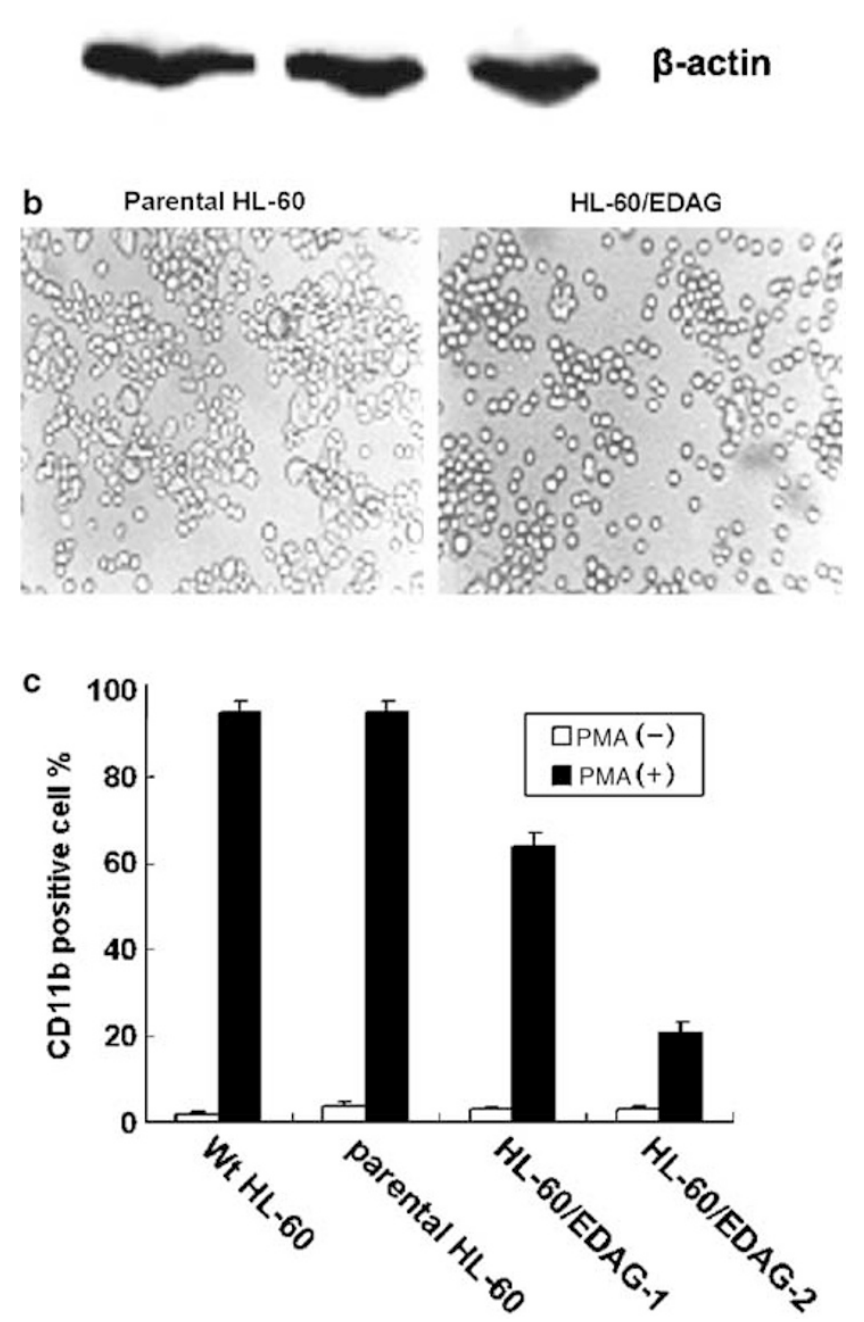

Figure 3 Expression of EDAG inhibits differentiation of HL-60 cells. (a) Detection of EDAG expression in HL-60/EDAG (clone 1, clone 2) and parental HL-60 (vector) cells by Western blotting. (b) Microphotograph of PMA-induced parental HL-60 cells and HL-60/EDAG cells $(\times 400)$. (c) CD11b expression in parental HL-60 and HL-60/EDAG cells. Cells were treated for 4 days with $10 \mathrm{nM}$ PMA, then incubated with anti-CD11b monoclonal antibody and analyzed by flow cytometry analysis. Data shown are means \pm s.e.

of NF- $\kappa \mathrm{B}$ (Figure $5 \mathrm{~b}$ ). To further confirm these results, the luciferase reporter vector was cotransfected with EDAG or $\triangle$ EDAG expression vector or control vector in NIH3T3 cells. The same results were obtained (Figure $5 b$ ).

\section{Induction of cell death correlates with inhibition of NF- $\kappa$ B activation}

To assess whether NF- $\kappa \mathrm{B}$ activity is necessary for $\mathrm{Ba} / \mathrm{F} 3$ EDAG cells viability, we examined the biological effect of the a
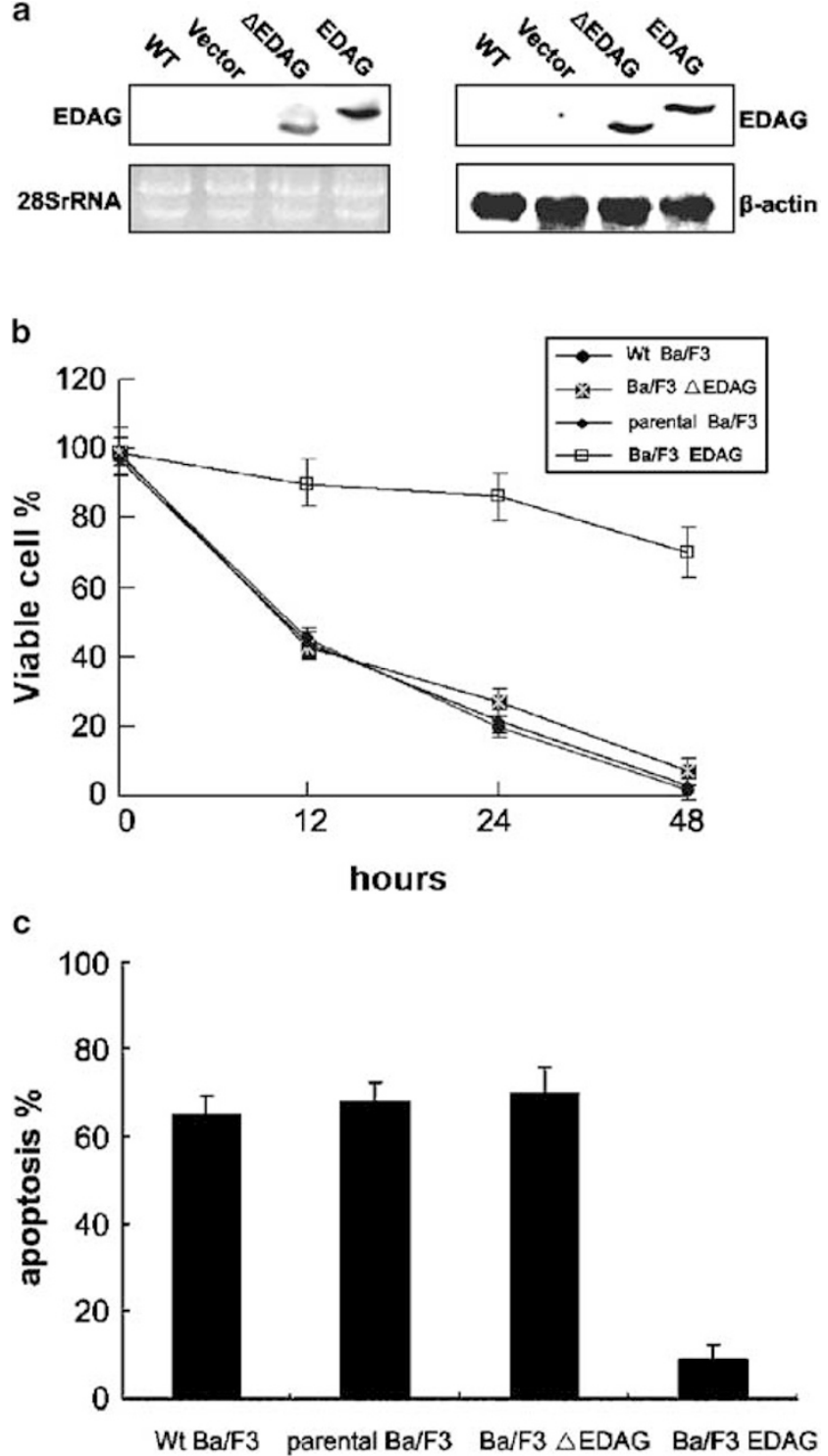

Figure 4 Overexpression of EDAG in $\mathrm{Ba} / \mathrm{F} 3$ cells prolonged survival and inhibited apoptosis. (a) Detection of expression of EDAG and $\triangle E D A G$ in $\mathrm{Ba} / \mathrm{F} 3$ cells by Northern blotting (left) and Western blotting (right). (b) Ba/F3 cells were washed with PBS three times and then seeded at a density of $1 \times 10^{4}$ cells/ $100 \mu \mathrm{l}$, cultured without IL-3, and the total number of viable cells was counted by trypan blue staining. The results shown are the means \pm s.e. of triplicate independent experiments. (c) Cells were cultured in the absence of IL-3 for $12 \mathrm{~h}$ and then the cells were harvested for the cell cycle analysis by a FACSCAN system

Bay 11-7082 compound on cell viability. Bay 11-7082 has been described as an irreversible inhibitor of $\mathrm{l} \kappa \mathrm{B}$ phosphorylation, which completely and specifically abrogates the DNAbinding activity of NF- $\kappa \mathrm{B}$. ${ }^{9}$ As shown in Figure $6 \mathrm{a}$, under IL-3 starvation conditions, when $\mathrm{Ba} / \mathrm{F} 3$ EDAG cells were treated with Bay 11-7082, a significant decrease in cell viability was observed $24 \mathrm{~h}$ after treatment. These results suggested that the activation of $\mathrm{NF}-\kappa \mathrm{B}$ is a contributing factor to cell survival induced by EDAG.

To further assess the potential role of NF- $\kappa$ B in the EDAGinduced survival of $\mathrm{Ba} / \mathrm{F} 3$ cells, we transfected $\mathrm{Ba} / \mathrm{F} 3 \mathrm{EDAG}$ 


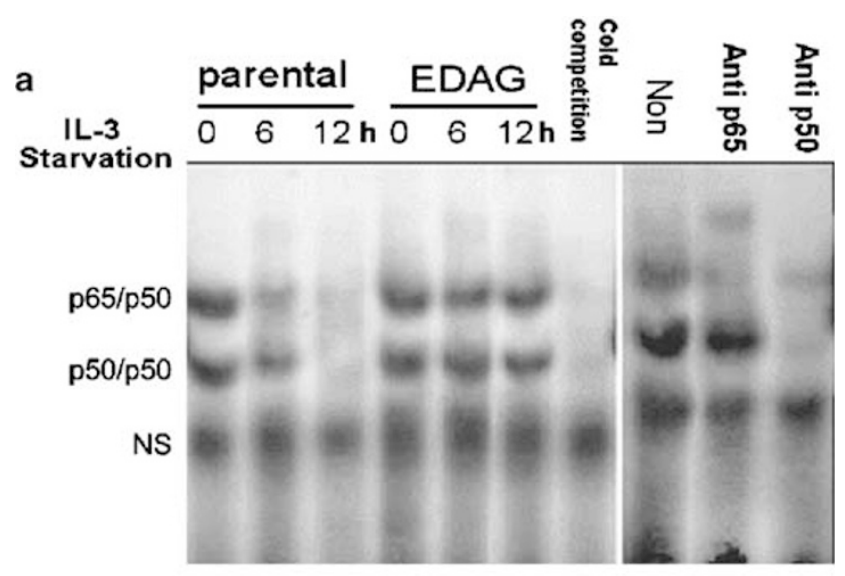

b

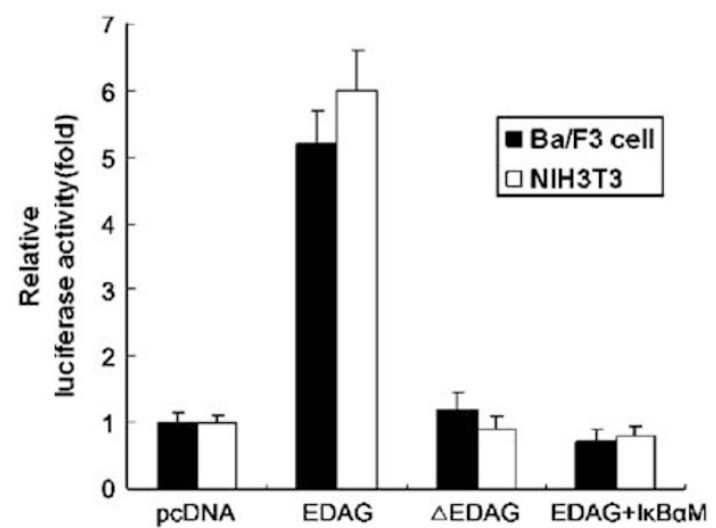

Figure 5 EDAG enhanced NF- $\kappa$ B DNA-binding and transcriptional activity. (a) EDAG enhanced NF- $\kappa$ B DNA-binding activity. Parental Ba/F3 and Ba/F3 EDAG cells were cultured in the absence of IL-3 for the indicated time and then the nuclear extracts were prepared for EMSA. For supershift, anti-p65 and anti-p50 antibodies were added. (b) EDAG enhanced NF- $\kappa$ B transcriptional activity. Parental $\mathrm{Ba} / \mathrm{F} 3, \mathrm{Ba} / \mathrm{F} 3 \triangle \mathrm{EDAG}$, and $\mathrm{Ba} / \mathrm{F} 3 \mathrm{EDAG}$ cells were transfected with a luciferase reporter gene $\left(3 \times \kappa \mathrm{B}\right.$-Luc) or $\mathrm{pCMV}-I_{\kappa} \mathrm{B} \alpha \mathrm{M}$ vector and then cultured for $36 \mathrm{~h}$ in the presence of $0.2 \mathrm{ng} / \mathrm{ml} \mathrm{IL-3}$, and the relative luciferase activity was measured. NIH3T3 cells were also contransfected with $3 \times \kappa \mathrm{B}$-Luciferase reporter vector and EDAG expression vector or $\triangle E D A G$ expression vectors or control vector, and then the luciferase activity was measured. The results are shown as the means \pm s.e. of triplicate experiments

cells with $p C M V-I_{\kappa} \mathrm{B} \alpha \mathrm{M}(\mathrm{A} 32 / 36)$ vector or a control $\mathrm{pCMV}$ vector. For the identification of transfected cells and to show the transfection efficiency, a construct encoding green fluorescent protein (GFP) was cotransfected into the cells. As Figure $6 \mathrm{~b}$ shows, $48 \%$ of $\mathrm{Ba} / \mathrm{F} 3$ EDAG cells transfected with the $\mathrm{pCMV}-\mathrm{I}_{\kappa} \mathrm{B} \alpha \mathrm{M}$ plasmid showed apoptosis, whereas less than $20 \%$ of cells transfected with the control pCMV vector exhibited apoptosis. These findings strongly support the speculation that NF- $\kappa$ B signaling is required for cell survival mediated by EDAG in Ba/F3 cells.

\section{EDAG-induced expression of c-Myc, Bcl-2 and Bcl-xL}

Previous studies have shown that several genes including $\mathrm{C}-\mathrm{Myc},{ }^{10} \mathrm{Bcl}-2^{11}$ and $\mathrm{Bcl}-\mathrm{xL}^{12}$ are involved in the regulation of a
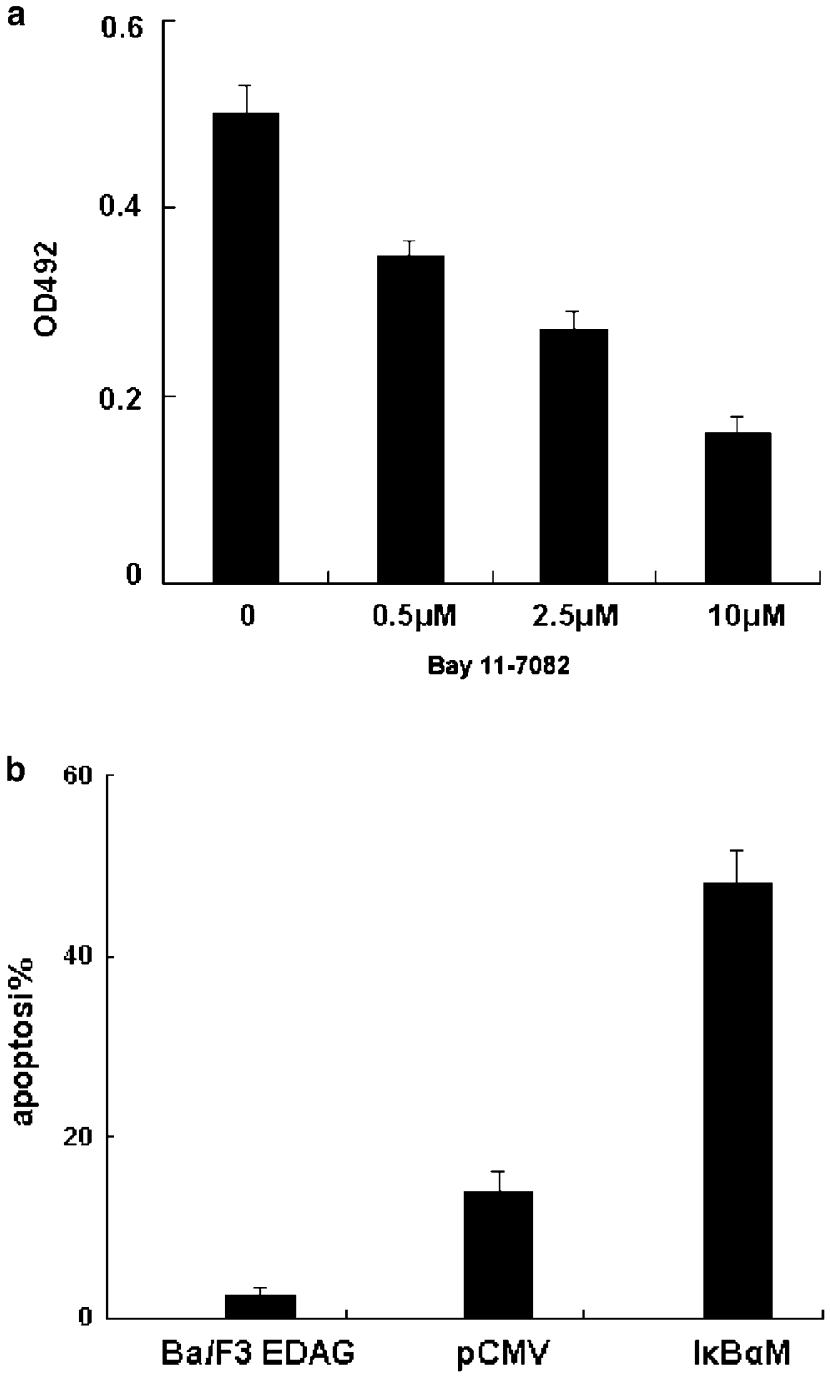

Figure $6 \mathrm{NF}-\kappa \mathrm{B}$ activity is necessary for the viability of $\mathrm{Ba} / \mathrm{F} 3 \mathrm{EDAG}$ cells. (a) Bay 11-7082 treatment inhibited the cell growth. A total of $3 \times 10^{4} \mathrm{Ba} / \mathrm{F} 3 \mathrm{EDAG}$ cells in the absence of IL-3 were seeded in a 96-well plate and treated with different concentrations of Bay 11-7082. Cell growth was determined after $24 \mathrm{~h}$. Error bars represent the standard deviation of three independent experiments. (b) Transfection of a nondegradable form of $l_{\kappa} \mathrm{B} \alpha$ induced the cells to apoptosis. $\mathrm{Ba} / \mathrm{F} 3 \mathrm{EDAG}$ cells were electroporated with $\mathrm{I}_{\kappa} \mathrm{B} \alpha \mathrm{M}$ plasmid or control vector and then the cells were cultured in the absence of IL-3. After electroporation for $36 \mathrm{~h}$, the cells were harvested and the apoptosis was measured by flow cytometry assay

survival in $\mathrm{Ba} / \mathrm{F} 3$ cells. Therefore, the effect of EDAG on the expression of these genes was examined in $\mathrm{Ba} / \mathrm{F} 3$. As shown in Figure 7 , both parental $\mathrm{Ba} / \mathrm{F} 3$ and $\mathrm{Ba} / \mathrm{F} 3$ EDAG cells expressed high levels of all these proteins in the presence of IL-3; however, $6 \mathrm{~h}$ after IL-3 was withdrawn, the proteins decreased dramatically in parental $\mathrm{Ba} / \mathrm{F} 3$ cells, whereas, in $\mathrm{Ba} / \mathrm{F} 3 \mathrm{EDAG}$ cells, they still retained a high expression level.

\section{Discussion}

Previous studies have characterized EDAG or hemogen as a hematopoietic gene with expression restricted to the 


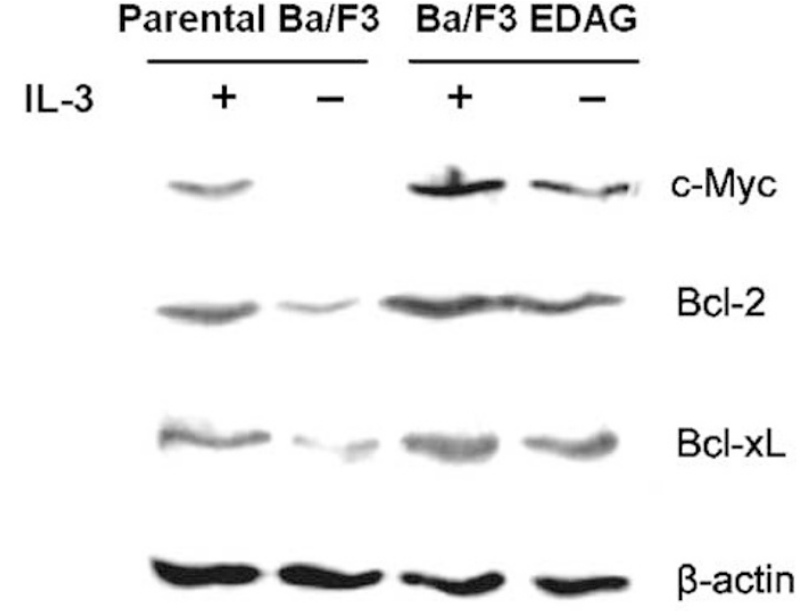

Figure 7 EDAG induced expression of c-Myc, Bcl-2 and $\mathrm{Bcl}-\mathrm{xL}$. Parental $\mathrm{Ba} / \mathrm{F3}$ cells and Ba/F3 EDAG cells were cultured with or without IL-3 for $6 \mathrm{~h}$ and then the expression of c-Myc, Bcl-2 and Bcl-xL was determined by Western blotting

hematopoietic system. However, the function of EDAG is poorly understood. In the present study, high expression of EDAG was detected in various types of human tissues and cells including thyroid tumor, thymus tumor, non-Hodgkin's lymphoma and PBMCs of patients with leukemia. EDAG expression was low in quiescent PBMCs and increased when cells were stimulated with IL-2 or PHA. Accumulated evidence has revealed that cytokine-inducible primary response genes play important roles in signal transduction controlling cell proliferation, differentiation and transformation. ${ }^{13,14}$ Our results also revealed that downregulation of EDAG by a zinc-inducible AS construct resulted in the inhibition of K562 cell growth and enhancement of differentiation sensitivity to hemin. Conversely, the enforced expression of EDAG in HL60 cells opposed differentiation induction by PMA. EDAG or hemogen is primarily expressed in immature precursors, such as the $\mathrm{Lin}^{\mathrm{lo}} \mathrm{C}-\mathrm{kit}^{+} \mathrm{Sca}-1^{+}$stem cell population, and CD34 ${ }^{+}$ progenitor cells, and is downregulated in mature blood cells. ${ }^{1}$ Downregulation of EDAG expression also occurs during erythroid differentiation of K562 cells induced by hemin and erythropoietin. ${ }^{4}$ In hematopoiesis, the pluripotent stem cells have to decide between self-renewal (i.e., proliferation) and entering differentiation pathways. During differentiation, the cells undergo a limited number of cell divisions, followed by terminal differentiation. However, in leukemia, progenitors derived from both pluripotent stem cells and multi- or unipotent progenitors can undergo long-term proliferation without entering terminal differentiation. ${ }^{15}$ The mechanisms of blocking hematopoietic differentiation are still not clear. Our results indicated that the overexpression of EDAG in leukemia cells caused increased proliferation and blocked their ability to undergo terminal differentiation, which suggested that EDAG may contribute to the development of leukemia. Moreover, overexpression of EDAG in NIH3T3 cells causes malignant transformation. Furthermore, EDAG is mapped to chromosome $9 q 22$, which is a breakpoint in several hematological neoplasms and contains a cluster of genes important for leukemogenesis. These results raise the possibility that the overexpression of EDAG may promote hematopoietic cell proliferation, inhibit differentiation and contribute to a leukemic phenotype.

The mechanisms of promoting growth and blocking differentiation of leukemic cells remain largely unknown. It is now well known that the level of c-Myc expression sets the balance between proliferation and differentiation. The downregulation of c-Myc expression appears to be necessary for the differentiation and maturation of hematopoietic cells. ${ }^{16,17}$ In differentiating K562 cells, the downregulation of c-Myc is observed, and the continuous expression of c-Myc transgene blocks induced differentiation. ${ }^{18}$ Moreover, oligonucleotides complementary to c-Myc mRNA ${ }^{19}$ or an inhibitory c-Myc mutant ${ }^{20}$ induce the differentiation of hematopoietic cells. Thus, changes in the level of c-Myc expression are essential to permit hematopoiesis. In the present experimental system, we showed that the c-Myc protein level decreased significantly after the inhibition of EDAG expression in K562 cells, providing evidence that c-Myc may be involved in signaling for regulation of hematopoietic proliferation and differentiation by EDAG.

We observed that overexpression of EDAG allowed Ba/F3 cells to survive in the absence of IL-3, and improvement in the viability in the Ba/F3 EDAG cells was secondary to a decrease in the percentage of cells undergoing apoptosis. In addition, we also observed that overexpression of EDAG protected $\mathrm{HL}$ 60 cells against the apoptosis induced by all trans retinoic acid (ATRA) (data not shown). Although the exact mechanism was not entirely clear, our results suggested a role of NF- $\kappa$ B in this process. Using EMSA and transcriptional luciferase reporter assays, we showed that the expression of EDAG enhanced $\mathrm{NF}-\kappa \mathrm{B}$ activity, and high DNA-binding activity of NF- $\kappa \mathrm{B}$ was sustained in Ba/F3 EDAG cells after IL-3 was withdrawn. Inhibition of NF- $\kappa \mathrm{B}$ activity by an NF- $\kappa \mathrm{B}$-specific inhibitor resulted in a significant inhibition of cell survival. Furthermore, the overexpression of a nondegradable form of $\mathrm{l}_{\kappa} \mathrm{B} \alpha$ to inhibit $\mathrm{NF}-\kappa \mathrm{B}$ activity greatly increased apoptosis in Ba/F3 EDAG cells. Therefore, we conclude that, just as described for IL-3 in $\mathrm{Ba} / \mathrm{F} 3$ cells, ${ }^{21} \mathrm{NF}-\kappa \mathrm{B}$ is a crucial mediator of the antiapoptotic signal delivered by EDAG.

Like NF- $\kappa \mathrm{B}, \mathrm{c}-\mathrm{Myc}, \mathrm{Bcl}-2$ and $\mathrm{Bcl}-\mathrm{xL}$ proteins have also been implicated in the regulation of $\mathrm{Ba} / \mathrm{F} 3$ cell survival. In the present study, overexpression of EDAG in pro-B Ba/F3 cells prolonged survival in the absence of IL-3; consistent with survival, the levels of $\mathrm{c}-\mathrm{Myc}, \mathrm{Bcl}-2$ and $\mathrm{Bcl}-\mathrm{xL}$ were maintained in $\mathrm{Ba} / \mathrm{F} 3$ EDAG cells, but not in parental cells when IL-3 was withdrawn. These findings suggested that CMyc, Bcl-2 and Bcl-xL were involved in pathways for EDAG signaling of $\mathrm{Ba} / \mathrm{F} 3$ cell survival. As reported, $\mathrm{c}-\mathrm{Myc}$ and $\mathrm{Bcl}-\mathrm{xL}$ are expressed as a consequence of NF- $\kappa \mathrm{B}$ activation, and $\mathrm{Bcl}-2$ expression is influenced by $\mathrm{NF}-\kappa \mathrm{B}$ activity in some experimental systems. ${ }^{22}$ However, the regulation of c-Myc, $\mathrm{Bcl}-\mathrm{xL}$ and $\mathrm{Bcl}-2$ expression appears to be complicated, mediated via NF- $\kappa \mathrm{B}$-dependent and -independent signaling pathways; thus, whether EDAG leads to the activation of these genes through NF- $\kappa$ B remains to be investigated.

The molecular mechanism by which EDAG mediates cell proliferation, differentiation and apoptosis also remains obscure. We treated Wt Ba/F3 cells with the supernatants of $\mathrm{Ba} / \mathrm{F} 3 \mathrm{EDAG}$ cells, and the supernatants could not stimulate 
Wt $\mathrm{Ba} / \mathrm{F} 3$ cells to survive or proliferate, as well as the supernatants of Wt Ba/F3 cells (unpublished data), which suggested that the growth regulation of EDAG was not caused by an autocrine mechanism. Previous studies have found that $\mathrm{STAT}^{23}$ and mitogen-activated protein kinase (MAPK) ${ }^{24}$ are phosphorylated in response to growth factors in $\mathrm{Ba} / \mathrm{F} 3$ cells. We found that the phosphorylation of STAT5 and ERK1/2 in $\mathrm{Ba} / \mathrm{F} 3 \mathrm{EDAG}$ cells is not higher than that in parental $\mathrm{Ba} / \mathrm{F} 3$ cells after IL-3 starvation for $12 \mathrm{~h}$ (unpublished data), which suggested that the expression of EDAG promoted $\mathrm{Ba} / \mathrm{F} 3$ viability in the absence of IL-3 without the activation of STAT5, or the MAPK cascade. Sequence analysis suggests that the putative EDAG protein $\mathrm{N}$-terminus sequence has a coiled-coil domain often found in oligomeric protein and is highly conserved in mouse and rat homology. ${ }^{1}$ As a structural basis for the interaction of protein with cellular cofactors, this motif has also been found in the N-terminus of c-Fos, ${ }^{25} \mathrm{Bcr}-\mathrm{Abl}$ oncoproteins, ${ }^{26} \mathrm{RAR}^{27}$ and AML1 transcription factor, ${ }^{28}$ and is essential for their biological activities of transformation, hematopoietic differentiation and transcription. We found that the overexpression of mutant EDAG ( $\triangle E D A G)$, which had a deletion in its $\mathrm{N}$-terminus that includes the coiled-coil domain of EDAG, did not have any transforming activity in NIH3T3 cells or prolong the survival of $\mathrm{Ba} / \mathrm{F} 3$ cells when IL-3 was withdrawn. These indicated that the $\mathrm{N}$-terminal 175 amino acids of EDAG might play an essential role in EDAG biological activity, and it seems that EDAG performs its regulatory functions through protein-protein interactions.

Taken together, the major finding of the present study is that the overexpression of EDAG in leukemia cells increases proliferation, blocks their ability to undergo terminal differentiation and protects cells from apoptosis through the activation of $\mathrm{NF}-\kappa \mathrm{B}$. Also, EDAG leads to increased levels of $\mathrm{c}-\mathrm{Myc}, \mathrm{Bcl}-2$ and $\mathrm{Bcl}-\mathrm{xL}$. Furthermore, the inactivation of EDAG may lead to the sensitization of leukemia cells to chemotherapeutic drug-induced differentiation and apoptosis.

\section{Materials and Methods}

\section{Plasmids}

The human full-length EDAG cDNA was obtained through PCR from the human fetal liver cDNA (Clontech). Then the fragment was inserted into pHSC vector in reverse orientation (pHSC-EDAG-R) or pcDNA3.1 $(+)$ plasmid (invitrogen) in correct orientation (pcDNA-EDAG). pHSC vector (kindly provided by Dr. Zhixian Sun, Beijing Institute of Radiation medicine, Beijing) was obtained from pcDNA3.1, in which cytomegalovirus (CMV) promoter was replaced by human metallothionein-II $A$ promoter from pHS1 vector. ${ }^{29}$ For the construction of mutated human EDAG vector (pcDNA- $\triangle E D A G$ ), a 525-bp deletion fragment in the $5^{\prime}$ terminus of EDAG encoding cDNA was cloned into pcDNA 3.1(+) plasmid.

\section{PCR}

Total RNA was reverse-transcribed (Promega) and amplified with PCR kits (Perkin Elmer) according to the manufacturer's instructions. The following specific primers were used: EDAG $5^{\prime}$ primer $5^{\prime}$-GAA AGG ACC AAT CTC ATT TGA AGC A-3', $3^{\prime}$ primer $5^{\prime}$-TCT CAG TAG GTC TTT TAC TAC AGA T-3'; G3PDH 5' primer 5'-ACC ACA GTC CAT GCC ATC AC-3', 3' primer
5'-TCC ACC ACC CTG TTG CTG TA-3'. The PCR products were electrophoresed on $1 \%$ agarose gels and photographed.

\section{Isolation and culture of PBMCs}

Human PBMCs were isolated by Ficoll-Hypaque gradient centrifugation as described elsewhere. ${ }^{30}$ The lymphocyte fraction was cultured in RPMI 1640 (Gibcol) medium containing 10\% fetal calf serum (FCS; Atlanta Biologicals) in the presence of $5 \mu \mathrm{g} / \mathrm{ml} \mathrm{PHA} \mathrm{(Sigma)} \mathrm{with} \mathrm{or} \mathrm{without}$ $6000 \mathrm{IU} / \mathrm{ml}$ IL-2 (Life Technologies).

\section{Patient samples}

Total RNA was extracted from different tumor tissues or cells collected at the time of diagnosis before initiation of treatment and Ficoll-separated PBMCs of 10 healthy volunteers. Human tumor array slot blot was purchased from BioChain Institute Inc. (Cat\# H1235706).

\section{Northern blot}

Total RNA was fractionated on $1 \%$ agarose gel that contained $0.6 \mathrm{M}$ formaldehyde, transferred to Genescreen plus membrane and hybridized to ${ }^{32} \mathrm{P}$-labeled cDNA probes. Hybridization to all probes was carried out at $68^{\circ} \mathrm{C}$ in $6 \times$ standard saline citrate (SSC), $5 \times$ Denhardt's solution, $1 \%$ sodium dodecyl sulfate (SDS) and $100 \mu \mathrm{g} / \mathrm{ml}$ single-stranded DNA. The blots were washed in $2 \times \mathrm{SSC} / 0.05 \%$ SDS for $20 \mathrm{~min}$ at room temperature, followed by $20 \mathrm{~min}$ washes in $0.1 \times \mathrm{SSC} / 0.1 \% \mathrm{SDS}$ at $50^{\circ} \mathrm{C}$ before exposure to an X-ray film. The probes for human EDAG, G3PDH and $\gamma$-globin were generated by PCR.

\section{Cell culture and induced differentiation}

Human erythroleukemia cell line K562 cells and human promyelocytic leukemia cell line HL-60 cells were maintained in RPMI 1640 medium with $10 \%$ heat-inactivated FCS, $2 \mathrm{mM}$ glutamine, $100 \mathrm{IU} / \mathrm{ml}$ penicillin, $100 \mu \mathrm{g} /$ $\mathrm{ml}$ streptomycin, $2 \mathrm{~g} / \mathrm{l}$ sodium bicarbonate and $10 \mathrm{mM}$ HEPES in a $37^{\circ} \mathrm{C}$ incubator with $5 \% \mathrm{CO}_{2}$. When differentiation was induced, exponentially growing K562 cells at a concentration of $3 \times 10^{5}$ cells $/ \mathrm{ml}$ were treated with $40 \mu \mathrm{M}$ hemin (Sigma). ${ }^{31} \mathrm{HL}-60$ cells were exposed to $10 \mathrm{nM}$ PMA. ${ }^{32}$ The murine IL-3-dependent pro-B cell line, Ba/F3, was purchased from the American Type Culture Collection (Rockville, MD, USA) and maintained in RPMl 1640 medium supplemented with $10 \%$ FCS and $1 \mathrm{ng} / \mathrm{ml}$ mouse IL-3 (Prepro-Tech, Rocky Hill, NJ, USA).

\section{Stable transfection}

Cells $\left(5 \times 10^{6}\right)$ were washed, resuspended in $0.5 \mathrm{ml}$ of ice-cold phosphate-buffered saline (PBS), mixed with linearized plasmid DNA $(15 \mu \mathrm{g})$ and subjected to electroporation $(960 \mu \mathrm{F} ; 220 \mathrm{~V})$ in a 0.4-cm-wide electroporation cuvette. Cells were then cultured in $10 \mathrm{ml}$ of complete RPMl 1640 medium for 2 days and selected with $800 \mu \mathrm{g} / \mathrm{ml} \mathrm{G} 418$ for 2 weeks. Monoclones of the transfectants were obtained using the limiting dilution method and identified by Western blotting.

\section{Western blotting}

Cells $\left(1 \times 10^{7}\right)$ were lysed with $30 \mu \mathrm{l} \mathrm{TNT}$ buffer $(20 \mathrm{mM}$ Tris- $\mathrm{HCl}(\mathrm{pH} 7.5)$, $200 \mathrm{mM} \mathrm{NaCl}, 1 \%$ Triton X-100, $1 \mathrm{mM}$ phenylmethylsulfonyl fluoride (PMSF), and protease inhibitors leupeptin, aprotinin, pepstatin $A$, chymostatin and antipain each at a final concentration of $10 \mu \mathrm{g} / \mathrm{ml}$ ). 
Then, $20 \mu \mathrm{g}$ of protein from each sample was loaded onto the gel. After separation by sodium dodecyl sulfate-polyacrylamide gel electrophoresis (SDS-PAGE), proteins were transferred to PVDF membranes and probed with various antibodies at the following concentrations: EDAG antiserum, 1:500; c-Myc (Santa Cruz Biotechnology, Santa Cruz, CA, USA; sc42), 1:1000; Bcl-2 (Santa Cruz; sc492), 1 : 1000; Bcl-xL (\#2762, Cell Signaling Technology), 1:1000; and $\beta$-actin (Santa Cruz; sc1616), 1:1000. Chemiluminescent detection was conducted using supersignal substrate (Pierce, Rockford, IL, USA) according to the manufacturer's specifications.

\section{Cell growth analysis}

K562 Cells were cultured in $100 \mu$ at a density of $3 \times 10^{5}$ cells $/ \mathrm{ml}$ in 96well microtiter plates with or without different concentrations of $\mathrm{ZnSO}_{4}$. After $48 \mathrm{~h}$, cellular proliferation was measured at various time points by adding $0.5 \mu \mathrm{Ci}$ of $\left.{ }^{3} \mathrm{H}\right]$ thymidine for $3 \mathrm{~h}$, after which cells were harvested onto glass-fiber filters. Radioactivity incorporated was quantitated by scintillation counting. For Ba/F3 cells, $3 \times 10^{4}$ cells were placed in 96 -well plates, treated with Bay $11-7082$ at $0.5,2.5$ or $10 \mu \mathrm{M}$ for $24 \mathrm{~h}$, and cell proliferation was detected using a nonradioactive cell proliferation assay kit (Promega) according to the manufacturer's instructions.

\section{Colony formation assay}

Cells were mixed with $1 \mathrm{ml}$ of top ultrapure agar $(0.3 \%)$. with or without different concentrations of $\mathrm{ZnSO}_{4}$ and plated in triplicate on top of $1 \mathrm{ml}$ of bottom ultrapure agar (0.6\%) in RPMl 1640 plus $20 \%$ FCS, G418 $(800 \mathrm{mg} /$ l), $100 \mathrm{U} / \mathrm{ml}$ penicillin and $100 \mu \mathrm{g} / \mathrm{ml}$ streptomycin at a density of $1 \times 10^{3}$ cells per 35-mm well. Cells were fed every $4-5$ days by adding a new layer of top agar. After 2 weeks, colonies that contained more than 50 cells were scored.

\section{Benzidine oxidation test}

Cells were washed twice with ice-cold PBS and then resuspended in icecold PBS. The benzidine solution $(3 \mu \mathrm{l})$, which contained hydrogen peroxide (final concentration $0.0012 \%$ ), was added and incubated for $10 \mathrm{~min}$ at room temperature. ${ }^{33}$ Benzidine-positive cells were quantitated under the microscope. At least 100 cells were counted in triplicate for each condition.

\section{Flow cytometry analysis}

Cells $\left(2 \times 10^{5}\right)$ were pelleted at $700 \times g$ for $5 \mathrm{~min}$ and washed with PBS containing $2 \%$ human albumin (PBS-AB). The cells were resuspended in $100 \mu \mathrm{l}$ PBS-AB with $2 \mu$ human CD11b monoclonal antibody (CD11b01-4, CALTAG Laboratories) conjugated with fluorescein isothiocyanate (FITC), incubated at $4^{\circ} \mathrm{C}$ for $20 \mathrm{~min}$ and washed twice with PBS-AB. The cells were resuspended in $400 \mu \mathrm{l}$ PBS-AB and were examined by flow cytometry using a FACSCAN system (Becton Dickinson).

\section{EMSA}

Nuclear extracts were isolated as described elsewhere. ${ }^{34}$ Nuclear extracts $(10 \mu \mathrm{g})$ were incubated with the binding buffer for $10 \mathrm{~min}$, followed by incubation with $0.5 \mathrm{ng}$ of ${ }^{32} \mathrm{P}$-labeled NF- $\kappa \mathrm{B}$ double-stranded oligonucleotides (top strand: 5'-AGT TGA GGG GAC TTT CCC AGG C-3'; bottom strand: $3^{\prime}$-TCA ACT CCC CTG AAA GGG TCC G-5'; Promega) at room temperature for $15 \mathrm{~min}$. The DNA-protein complexes were analyzed on a $4 \%$ polyacrylamide gel in $0.5 \times$ Tris borate/ethylene diaminetetraacetic acid (EDTA) electrophoresis buffer at $250 \mathrm{~V}$. Gels were vacuum-dried and exposed to a Fuji X-ray film at $-80^{\circ} \mathrm{C}$ for $10-12 \mathrm{~h}$. For competition experiments, a 50 -fold excess of unlabeled double-stranded oligonucleotides of NF- $\kappa \mathrm{B}$ was added prior to the oligonucleotide probe. In supershift assays, $2 \mu \mathrm{g}$ of antibodies against p65 (sc-372x) or p50 (sc-1191x) (Santa Cruz Biotechnology) was added to the nuclear extracts for $30 \mathrm{~min}$ before the addition of oligonucleotide probe.

\section{Luciferase reporter assays}

A total of $5 \times 10^{6}$ cells were cotransfected with $3 \times \kappa \mathrm{B}$-luciferase reporter gene (Stratagene) and Renilla luciferase expression vector pRL-TK (Promega) for the normalization of transfection efficiency by electroporation as described above. Cells were collected $36 \mathrm{~h}$ after transfection and lysed in $400 \mu$ l of $1 \times$ passive lysis buffer (Promega). Luciferase assays were carried out with $50 \mu$ l lysate using the Dual-luciferase reporter assay system (Promega) in a chemiluminescence analyzer (FB12 luminometer; Berthold Detection Systems). Luciferase activities are expressed as fold induction relative to values obtained from control cells.

\section{Acknowledgements}

This work was supported by the Chinese National Distinguished Young Scholar Award (30025018), Beijing Natural Science Foundation key Project (7021003), Hi-Tech Research and Development Program of China (2001AA221321), Chinese National Natural Science Foundation project (30170464) and Chinese National Natural Science Fund for the Popularization of Science (30321003).

\section{References}

1. Yang LV, Nicholson RH, Kaplan J, Galy A and Li L (2001) Hemogen is a novel nuclear factor specifically expressed in mouse hematopoietic development and its human homologue EDAG maps to chromosome $9 q 22$, a region containing breakpoints of hematological neoplasms. Mech. Dev. 104: 105-111

2. Wurtz T, Kruger A, Christersson C and Lundmark C (2001) A new protein expressed in bone marrow cells and osteoblasts with implication in osteoblast recruitment. Exp. Cell Res. 263: 236-242

3. Xu WX, Wei HD, Wang SY and Yang XM (2001) Isolation of specific expression gene in human fetal liver by representational difference analysis. Chin. J. Appl. Physiol. 17: 192-194

4. Lu J, Xu WX, Wang SY, Zhan YQ, Jiang Y, Cai WM and Yang XM (2001) Isolation and characterization of EDAG-1, a novel gene related to regulation in hematopoietic system. Sheng Wu Hua Xue Yu Sheng Wu Wu Li Xue Bao (Shanghai) 33: 641-646

5. Lu J, Xu WX, Wang SY, Jiang Y, Li CY, Cai WM and Yang XM (2002) Overexpression of EDAG in NIH3T3 cells leads to malignant transformation [article in Chinese]. Sheng Wu Hua Xue Yu Sheng Wu Wu Li Xue Bao (Shanghai) 34: 95-98

6. Johansson B, Fioretos T and Mitelman F (2002) Cytogenetic and molecular genetic evolution of chronic myeloid leukemia. Acta Haematol. 107: 76-94

7. Kruger A, Ellerstrom C, Lundmark C, Christersson C and Wurtz T (2002) RP59, a marker for osteoblast recruitment, is also detected in primitive mesenchymal cells, erythroid cells, and megakaryocytes. Dev. Dyn. 223: 414-418

8. Pae HO, Seo WG, Kim NY, Oh GS, Kim GE, Kim YH, Kwak HJ, Yun YG, Jun $\mathrm{CD}$ and Chung HT (2001) Induction of granulocytic differentiation in acute promyelocytic leukemia cells (HL-60) by water-soluble chitosan oligomer. Leuk. Res. 25: 339-346

9. Keller SA, Schattner EJ and Cesarman E (2000) Inhibition of NF-kappaB induces apoptosis of KSHV-infected primary effusion lymphoma cells. Blood 96: 2537-2542 
10. Bourgeade MF, Defachelles AS and Cayre YE (1998) Myc is essential for transformation by TEL/platelet-derived growth factor receptor beta (PDGFRbeta). Blood 91: 3333-3339

11. Mahmud N, Katayama N, Nishii K, Sugawara T, Komada $Y$, Mitani H, Araki $H$, Ohishi K, Watanabe M, Masuya M, Nishikawa M, Minami N, Ohashi $\mathrm{H}$ and Shiku H (1999) Possible involvement of bcl-2 in regulation of cell-cycle progression of haemopoietic cells by transforming growth factor-beta1. $\mathrm{Br}$. J. Haematol. 105: 470-477

12. Dumon S, Santos SC, Debierre-Grockiego F, Gouilleux-Gruart V, Cocault L, Boucheron C, Mollat P, Gisselbrecht S and Gouilleux F (1999) IL-3 dependent regulation of $\mathrm{Bcl}-\mathrm{xL}$ gene expression by STAT5 in a bone marrow derived cell line. Oncogene 18: 4191-4199

13. Hunter T (1997) Oncoprotein networks. Cell 88: 333-346

14. Herschman HR (1991) Primary response genes induced by growth factors and tumor promoters. Annu. Rev. Biochem. 60: 281-319

15. Adams JM and Cory S (1992) Oncogene co-operation in leukaemogenesis. Cancer Surv. 15: 119-141

16. Dimberg A, Bahram F, Karlberg I, Larsson LG, Nilsson K and Oberg F (2002) Retinoic acid-induced cell cycle arrest of human myeloid cell lines is associated with sequential down-regulation of $\mathrm{c}-\mathrm{Myc}$ and cyclin $\mathrm{E}$ and posttranscriptional up-regulation of p27(Kip1). Blood 99: 2199-2206

17. McArthur GA, Foley KP, Fero ML, Walkley CR, Deans AJ, Roberts JM and Eisenman RN (2002) MAD1 and p27(KIP1) cooperate to promote terminal differentiation of granulocytes and to inhibit Myc expression and cyclin E-CDK2 activity. Mol. Cell Biol. 22: 3014-3023

18. Delgado MD, Lerga A, Canelles M, Gomez-Casares MT and Leon J (1995) Differential regulation of Max and role of c-Myc during erythroid and myelomonocytic differentiation of K562 cells. Oncogene 10: 1659-1665

19. Collins JF, Herman P, Schuch C and Bagby Jr. GC (1992) c-myc antisense oligonucleotides inhibit the colony-forming capacity of Colo 320 colonic carcinoma cells. J. Clin. Invest. 89: 1523-1527

20. Canelles M, Delgado MD, Hyland KM, Lerga A, Richard C, Dang CV and Leon $\mathrm{J}$ (1997) Max and inhibitory c-Myc mutants induce erythroid differentiation and resistance to apoptosis in human myeloid leukemia cells. Oncogene 14: $1315-1327$

21. Besancon F, Atfi A, Gespach C, Cayre YE and Bourgeade MF (1998) Evidence for a role of NF-kappaB in the survival of hematopoietic cells mediated by interleukin 3 and the oncogenic TEL/platelet-derived growth factor receptor beta fusion protein. Proc. Natl. Acad. Sci. USA. 95: 8081-8086

22. Bush JA and Li G (2003) The role of Bcl-2 family members in the progression of cutaneous melanoma. Clin. Exp. Metast. 20: 531-539
23. Spiekermann K, Pau M, Schwab R, Schmieja K, Franzrahe $S$ and Hiddemann W (2002) Constitutive activation of STAT3 and STAT5 is induced by leukemic fusion proteins with protein tyrosine kinase activity and is sufficient for transformation of hematopoietic precursor cells. Exp. Hematol. 30: $262-271$

24. Ho JM, Nguyen MH, Dierov JK, Badger KM, Beattie BK, Tartaro P, Haq R, Zanke BW, Carroll MP and Barber DL (2002) TEL-JAK2 constitutively activates the extracellular signal-regulated kinase (ERK), stress-activated protein/Jun kinase (SAPK/JNK), and p38 signaling pathways. Blood 100: 1438-1448

25. Chevray PM and Nathans D (1992) Protein interaction cloning in yeast: identification of mammalian proteins that react with the leucine zipper of Jun. Proc. Natl. Acad. Sci. USA 89: 5789-5793

26. McWhirter JR, Galasso DL and Wang JY (1993) A coiled-coil oligomerization domain of $\mathrm{Bcr}$ is essential for the transforming function of Bcr-Abl oncoproteins. Mol. Cell Biol. 13: 7587-7595

27. Pfitzner E, Becker P, Rolke A and Schule R (1995) Functional antagonism between the retinoic acid receptor and the viral transactivator BZLF1 is mediated by protein-protein interactions. Proc. Natl. Acad. Sci. USA 92 : $12265-12269$

28. Harada H, Harada Y, O'Brien DP, Rice DS, Naeve CW and Downing JR (1999) HERF1, a novel hematopoiesis-specific RING finger protein, is required for terminal differentiation of erythroid cells. Mol. Cell Biol. 19: 3808-3815

29. Haslinger A and Karin M (1985) Upstream promoter element of the human metallothionein-IIA gene can act like an enhancer element. Proc. Natl. Acad. Sci. USA 82: 8572-8576

30. Coligan JE, Kruisbeek AM, Margulies DH, Shevach EM and Stober W (eds) (1991) Current Protocols in Immunology Vol. 1 New York: John Wiley and Sons pp 7.1.1-7.1.3

31. Baliga BS, Mankad M, Shah AK and Mankad VN (1993) Mechanism of differentiation of human erythroleukaemic cell line K562 by hemin. Cell Prolif. 26: $519-529$

32. Seo J, Kim M and Kim J (2000) Identification of novel genes differentially expressed in PMA-induced HL-60 cells using cDNA microarrays. Mol. Cells 10: 733-739

33. Athanasiou M, Mavrothalassitis G, Sun-Hoffman and Blair DG (2000) Fli-1 is a suppressor of erythroid differentiation in human hematopoietic. Leukemia 14: $439-445$

34. Dumon S, Santos SC, Debierre-Grockiego F, Gouilleux-Gruart V, Cocault L, Boucheron C, Mollat P, Gisselbrecht S and Gouilleux F (1999) IL-3 dependent regulation of $\mathrm{BCl}-\mathrm{xL}$ gene expression by STAT5 in a bone marrow derived cell line. Oncogene 18: 4191-4199 